\title{
THE NATIVENESS OF BRETON SPEAKERS AND THEIR ERASURE
}

\author{
MÉLANIE JOUITTEAU \\ Centre National de la Recherche Scientifique / French National Centre for \\ Scientific Research; CNRS, IKER (UMR 5478)
}

\begin{abstract}
I discuss the nativeness of heritage speakers of Breton in the twentieth century. I present a syntactic test designed for Breton that sets apart its native speakers from its late learners, for whom Breton is a second language. Nativeness is revealed by a better tolerance to syntactic overload when sufficient linguistic stress is applied. Both heritage speakers of inherited Breton and early bilinguals whose linguistic input comes exclusively from school answer this test alike, which I take as a sign they are cognitively natives. The syntactic nativeness of children deprived of familial Breton input suggests there is many more young Breton natives among contemporary speakers than previously assumed. Taking stock of these results, I discuss the cultural erasure of Breton native speakers. I compare their cultural treatment with the figure of the ghost. I end by a discussion of the term new speaker.
\end{abstract}

Keywords: nativeness, new speaker, Breton, heritage language

The article has two main sections. In the first section, I discuss the question of nativeness in Breton, a Celtic heritage language spoken in Brittany. I present what constitutes nativeness for formal and cognitive linguistics, and what parameters impact nativeness. Following Schutter (2013), I show how nativeness may be revealed by tests ${ }^{1}$ that engineer linguistic stress. I report on a pilot study designed

${ }^{1}$ The syntactic tests in this paper have been elicitated by the author with Breton adult speakers in
their twenties to fifties. The raw data can be found on line, on the Elicitation Center of ARBRES,
the Breton wikigrammar (http://arbres.iker.cnrs.fr). Each elicitation is given a reference between
brackets [name (date of elicitation)] and corresponds to a page of transcript of the results of the
elicitation. Speakers are identified by either their full name, an acronym or a pseudonym, 
for Breton, and conclude about the nativeness of different profiles of speakers. In the second section, I present some aspects of the cultural erasure of these Breton natives, in public or academic discourse. I present concrete examples of social interactions that fall under the generalisation that the culture treats them as symbolic ghosts: associated with the past, either invisible or posing an existential threat.

\section{Native heritage speakers vs. L2 speakers}

In this section, I first inventory the parameters between natives and late learners of a language. I first tentatively define the terms as they are used in cognitive linguistics and sociolinguistics. I show that the notions of home language and inherited variety more accurately boil down to nativeness, as constituted by gradient parameters such as (i) critical age of exposure and (ii) consistency of the input. I discuss these parameters for the Breton situation, and show how they lead to different profiles of native speakers.

\subsection{What is cognitive nativeness, and why bother about it at all?}

The notion of nativeness developed here is cognitive nativeness, and I am saying that sociolinguistic researchers also need this term. This requires some preliminary introduction on how those terms are used in both fields.

Rampton (1990:98) considers that in sociolinguistics, the concepts of mother tongue and native language should be done entirely away with because they "spuriously emphasize the biological at the expense of the social". It is important to see that for him, these terms "describe the ties between speakers and languages", not the languages themselves, nor the cognitive faculty of language as they are instantiated in a given speaker. His criticism rejects an unexamined emphasis on biological bounds between speakers, which does not say anything about the biological or innate dimension of early exposure to a given language, nor on its consequences for later linguistic competences during life. In the same vein, Kasstan (2019) rejects "the study of native speakers seen as the most traditional or authentic (and thus legitimate) representatives of a speech community - at the expense of more recent arrivals, whose language production has been viewed in terms of deficit (these speakers are typically labelled $L 2$ or learner, etc.)." He adds that "such essentialist perspectives on

\footnotetext{
depending on their personal choice on the matter. For a study on the replicability of data obtained by elicitation techniques, see Sprouse and Almeida (2012) who show that for the 469 data points of a widely used syntax manual, the minimum replication rate was $98 \%$. For a methodological study of the use of grammaticality judgments, see Bader and Häussler (2010). I would like to thank the speakers here for their trust and enthusiasm, as well as the editors and four anonymous reviewers who provided comments on the present article.
} 
language and identity follow from an ideology of language (and fluency) as inherited by birth". The link between, on the one hand, people who are cognitively natives of a language, and on the other hand, an identity or an intrinsic value assigned to these people, is indeed a social representation. Saying or implying that such a link is natural or biologically grounded is unjustified and resorts to ideology.

Cognitive linguistics is not concerned with social representations, or more precisely, it is concerned only with the scientific construction of our representations of linguistic realities. The terms of mother tongue, learning, native speaker vs. $L 2$ denote specific entities, irrespectively of their potential emotional charge. The expression mother tongue is justified in research contexts testing linguistic exposure in utero: it constitutes the linguistic input that a baby receives from a person when inside the uterus of that person. As for the expressions native language or inheritance by birth, they should not induce that the experience of being born is more than a necessary condition for language proficiency to develop. In this strict sense, no language fluency is ever "inherited by birth". The term of native is clumsy in that it denotes in fact a multi-factorial and gradient property. The opposite expressions native language and L2 language are however necessary because consistent exposure to a human linguistic variety produces different cognitive processes depending on the age of onset, and different grammars result from it. The expression native language competence denotes the linguistic competence that humans develop when they have been provided with consistent linguistic input since birth, or by extension, at a very early age, typically before three to five years old. Kasstan (2019) rejects the term $L 2$ because of its association with a negative value, a "deficit". In the fields of cognitive, formal and descriptive linguistics, L2 learners do have to be associated with a deficit. L2 learners do not demonstrate the exceptional brain plasticity of children, and as a result their grammars are different. Their competence and their overall performance can only be inferior when compared to native competence and performance, because the later is by definition their target language. The use of different verbs, acquire and learn, denote different cognitive processes: native languages are acquired, whereas adults typically learn a language. Adults learners typically have recourse to learning techniques unavailable to babies (grammars, lists of irregular verbs, exercises, etc.). Pedagogical immersion techniques try to reproduce for adults the acquisition processes available to young children, with various degrees of success. The cognitive change from the process of early language acquisition to the one of late language learning is gradual, and shows individual variation, but there is definitely a biological maturation process that makes us humans different linguistic creatures depending on our age. 
Sociolinguists question (the representations of) nativeness, which should not prevent them from using the term of (cognitive) nativeness. Banning entirely the expression native speakers from the sociolinguistic literature prevents sociolinguists from conducing an informed study on the variations they observe, and impoverishes the cross-disciplinary enrichment of cognitive linguistics and sociolinguistics. Let me illustrate this more precisely. Early exposure is a necessary condition for most people to pronounce a string of more than three consonants or clicks. It is unreasonable to study the sociolinguistic dimension of their production by adults without documenting who among them actually had access to an early input. Whatever the social representations assigned to producing these sounds, native speakers and L2 speakers pronouncing them are doing very different things, both socially and cognitively. Native speakers did not need training because they attained perfect performance with little effort, whereas successful L2 speakers producing them demonstrate extraordinary aptitudes and extensive training. The cognitive process they each operate is also different, as are the locations of the brain that they each mobilise.

In the name of the pragmatism of applied linguistics, some scientists openly recommend ignoring cognitive differences between natives and non-natives (Davies 2013:23). They propose focusing on the notion of new speakers, regardless of the nativeness of their practice. This is understandable to the extent speakers need only the type of high proficiency attainable for L2 learners in everyday life. Computational linguists need experts, not necessarily natives. However, this line of academic work typically sends the native/non-native divide into the socio-political dimension of the concept, for which nativeness is a problematic representation. The danger is that erasure of young natives in the representations aligns with the narratives of dominant nationalisms. These narratives have a powerful and direct effect on the funding affected to linguistic policies in the French context. Ignoring these effects in the name of pragmatism is non-sensical. Academic work that focuses exclusively on the politicization of the notion of nativeness certainly should not be blind to the political impact of their work in the extra-linguistic world.

In the following sections, I will present two main criteria for nativeness : critical age of exposure and consistency of the input. I start by introducing the reader with the less controversial case of Breton young natives who received consistent input since birth.

\subsection{Young natives with familial transmission}

There is a consensus that children who have received consistent linguistic input at home since birth are natives of that language. Young adults who were raised in Breton by at least one of their parents also unambiguously qualify as natives. 
Such speakers of inherited Breton exist in Breton. They are estimated 9\% of the Breton speakers under 40 years old in Karaez in the report from the Public Office Of Breton OPAB (2014), and even 10\% of all Breton speakers in the Regions Institute survey TMO (20182). OPAB (2014) also finds an extra 8\% of the speakers who declare they acquired Breton from their grandparents. OPAB (2014) considers that familial transmission was at its lowest in the 80s and 90s, but that it is not decreasing anymore: in Karaez at least, the younger the Bretonspeaking parents are, the more they speak Breton with their children. ${ }^{3}$

Jouitteau (2018) has studied in detail the syntactic dialectal flexibility of such a speaker of inherited Breton who had also received Breton schooling in an immersion school, the Diwan school system ([Brendan Corre (12/2017)]). The speaker received Breton input at home from his mother and maternal grandparents, all of whom were native speakers from Treger. As a working young adult, he reports no interruption of linguistic practice, with various Breton-speaking contacts in everyday life in the countryside. Much like a prototypical speaker of a traditional dialect, he produces syntactic forms that are specific to his Southern Treger dialect (Prat). He understands Standard Breton forms and structures, but considers them incorrect in his own Breton. He recognizes none of the forms typical of other traditional dialects. Jouitteau (2018) thus concludes that his productions are typical of a traditional speaker, with no greater dialectal flexibility than a speaker two generations older, apart from his good passive understanding of Standard Breton, due to schooling.

The syntactic portrait of young traditional speakers is of particular interest when reflecting on the potential differences between old natives of the Breton language and young generations schooled in Breton. Dołowy-Rybińska (2017) interviewed a sixteen-year-old Diwan pupil who highlights the contrast between her own situation, without Breton speakers at home, and that of her schoolmates who do have Breton-speaking families. This is of importance because first, the existence of "inherited Breton" speakers among contemporary teenagers is

2 Note that at the moment of writing this study, only the main results of TMO (2018) have been announced to the press. The text of the work has not been published yet, and its methodology is yet unknown. 10\% was also the maximal estimation of Davalan (1999:99).

3 There is the possibility that a number of the parents interviewed for OPAB (2014) are not Breton natives themselves. This is certainly a factor of change for the language, with possible influences of French-like structures, or of Standard Breton on the local variety. This impacts on the transmitted language, but this does not impact the cognitive nativeness of this variety for their children. Even children in contact with drastically syntactically empoverished structures like pidgins end up speaking syntactically complex languages like creoles. Likewise, deaf children, if not isolated from each other, create among themselves syntactically complex sign languages (Goldin-Meadow 2003). Complex grammar systems are not invented by adults and later taught to children; it is what grows in children and persists in them as adults in normal conditions. 
obvious to her, and second, she testifies that she is herself in daily linguistic contact with native speakers of inherited Breton of her own age. Recall here that Diwan, for most pupils, is a boarding school. From secondary school (skolaj) to high school (lise), which is from 11 to 18 years old, geographical distance with the families implies full time contact between teenagers during the school week. This is particularly clear for the high school, as there still exists only one in the entire country. The representation that children schooled in Diwan never speak with natives is thus an impossible scenario because they are actually raised among them. ${ }^{4}$ Young natives with traditional transmission of the language at home are schooled among a majority of children for whom Breton is not spoken at home. At an age where linguistic group norms are of importance, we should expect high sociolinguistic cross-influences between these two groups, in both directions.

The assessment of nativeness is less obvious for children who received early consistent Breton input, but exclusively outside of the home. Nativeness thus depends on different factors such as the age of first exposure and the consistency of the input they receive. This is discussed in detail in the next section.

\subsection{Critical age of exposure}

Early cognitive studies have postulated the existence of a critical stage for the acquisition of syntax. It means that a child can no longer attain native-like proficiency in a language after a certain age of exposure (Penfield \& Roberts 1959, Lenneberg 1967). Different lines of evidence support this hypothesis for syntax. I will briefly present here some arguments from different empirical domains, ranging from linguistic input impoverishments, cognitive dysfunctions, and studies using magnetic resonance imaging.

The most debated cases may be that of "wolf-children" raised outside human linguistic contact and that show an impoverished syntax. The fact that they never fully recover from their early deprival of linguistic input clearly reveals an age-dependent effect of language acquisition in terms of ultimate attainment. Deaf late signers provide another case study. Mayberry (1993) has compared two groups of adults learning American Sign Language. The first group was deaf by birth and was not previously signing in any other language; they were therefore learning a first language in adulthood. The second group consisted of people who became deaf after developing an oral language as their first language. As predicted by the hypothesis of a critical stage for the acquisition of

$4 \quad$ It is a widely known fact in Brittany that schooling does not automatically ensure intercomprehension between young children and speakers of the generation of their grandparents. For a study of the syntactic distance between dialects, including Standard Breton, and a discussion of crossdialectal comprehension, see Jouitteau (2019). 
a first language, the first group showed poorer performances. Another argument coming from a case of input impoverishment comes from people who are both deaf and blind. We know of examples like Hellen Keller, who became deaf and blind at the age of 18 months and developed with appropriate training a normal command of the language through touch. Babies born blind and deaf in environments that do not develop language by touch before a critical age do not later develop complex syntax (Smith 2002: 13-17). Likewise, the quality of recovery after acquired aphasia depends on the age at which aphasia has struck (Lenneberg 1967). Recovery is rarely complete when the injury occurs after puberty (with rare counterexamples, see Vargha-Khadem \& al 1997). Finally, the few individuals with Down syndrome who achieve normal language proficiency are those whose language development was completed before the age of puberty (Rondal 1995). According to studies that have operationalized Magnetic Resonance Imaging (MRI), the fronto-cortical area of a native language and a second language learned in adulthood form two separate spaces. The frontocortical area of a native language and an early second language are coincidental, whereas a language learned later in life occupies another area (Kim \& al. 1997, Dehaene \& al. 1997, Wattendorf \& al. 2001). Still according to MRI, the very early practice of a language, even if interrupted, leaves traces in the brain (Pierce \& al., 2015): children who spoke Chinese before French react differently from French monolinguals in the face of French-like invented words. This is true whether they always practise their first language or not. To date, the exact nature of what MRI measures remains unclear, but this definitely indicates that there is a quantifiable cognitive difference between early bilingualism and late bilingualism.

The threshold for native-like acquisition of a first language is gradual from pre-birth to puberty, and some individual variation is observed, but the critical age of first exposure is not usually assumed to be under three years old ${ }^{5}$. This plays in favour of the nativeness of Breton for children coming from monolingual French households, because the age of schooling in the French state is also around two or three years old, which is much earlier than in most European countries. The age of exposure to Breton is sometimes even lower

$5 \quad$ Laka and al. (2012) however found a brain signature signal (by means of ERP, Event-Related Potential) that distinguishes Basque native speakers from high proficient Basque speakers who had first Basque input as early as three years old, specifically for tests involving syntactic parameters set in opposite ways in Basque and Spanish (head-parameter, ergative case morphology, etc.). Díaz and al. (2016) replicate with tests on agreement and conclude that non-native syntactic processing approximates native processing for early L2 acquisition (input since four years old) and high proficiency levels of late learners when the syntactic property is common to the L1 and L2. This means that signs of nativeness also depend on the typological distance beween the two languages of bilinguals. 
because a growing network of nurseries offers immersion in Breton since the end of the 90s (OPAB 2017, Le Pelleter 2017, 2018). Their number is still low: OPAB (2017) has counted 3000 children below three years old who had received at least some Breton linguistic input in nurseries in 2016, only 45 of whom were in a Breton-speaking environment for half or more of the time. For the moment, the former represents $1.9 \%$ of children in Brittany, and the latter $0.03 \%$. The impact of this minority of children on future language development should however not be underestimated.

Mermet (2006), in the early 2000s, has recorded and quantified the number of linguictic productions done in Breton by kindergarten children in Pluvigner (vannetais). The age of exposure is one of the two key factors that he finds, with a doubling of the linguistic productions in Breton for the children who came into contact with it in the first year of kindegarten compared to those who integrated kindergarten in the second year (Mermet 2006: 98).

\subsection{Consistency of the input}

Consistency of the input (duration, quality, diversity) is another recurring key factor for the constitution of nativeness. Mermet (2006: 91) shows that there is a difference in the quantity of productions between children who stay in Breton kindergarten only during the mornings and children who also stay for lunch, napping time and afternoon. Richer contact leads to grammatical developments that are not observed in the children with less exposure to Breton, such as the maturation of the adressee. Children aged 2 to 3 years speak to themselves or to an underspecified global entity, demonstrating a rather erratic adressee for their linguistic messages. Most of their utterances are repeated directly from the context. In a second phase, the grammatical concept of addressee emerges and the utterances are specifically directed towards another child or the teacher. This period of maturation of the adressee corresponds to a growing number of original utterances, with the child creating sentences of her own. This step is not observed in children with poorer levels of language exposure. This means that when these children eventually catch up later and start building syntactic structures of their own to produce original Breton sentences, they will probably have to resort to partial transfer of syntactic structures previously built in French in order to do so (Stephens 2000), hence performing a different cognitive operation.

Among the non-traditional younger generations of speakers included in the fieldwork of Kennard $(2014,2018)$, there is a cross-generational maintenance of the verb-second rule, however with consistent interpersonal variations, one of which depends on the type of input they have received in Breton schooling (bilingual vs. immersion). The natives by immersion give results similar to the 
older generations, minor some differences due to diglossia and the general impoverishment of the linguistic input available to them. Children who received reduced Breton input at school and are also deprived of Breton input at home constitute here a class with late learners. They show reduced autonomy in their Breton grammar, and a greater influence of French structures.

Consistency of the input is a question for all modern native Breton speakers, in the sense that even speakers of inherited Breton that work in the language as adults still face diglossia in different domains. This type of acquisition is comparable to the situation of immigrants that receive input in their parents' language since an early age, but develop in contact with the dominant language of their country of immigration. Some contrasts have to be noted between immigrant languages and languages that are minorized in-situ. First, assuming that the language that migrants use at home are actually a majority language elsewhere, it can be contrasted with the language of a home country that could provide the linguist with a baseline for comparison. Second, immigrant heritage languages prototypically show a phonology that is similar to the baseline, even when their productions are syntactically deviant or impoverished (Hualde 2015). The contemporary speakers of Breton seem to resist much better French influence in their syntax than in their accentuation. This may be related, or not, to the fact that the early input of children contains productions of L2 speakers of different levels of proficiency, even inside the school system. This is not prototypical of immigrant languages. ${ }^{6}$

\subsection{Linguistic stress as a test for nativeness}

Nativeness is easy to assess in monolingual cases. A child speaks a human language, or fails to do so entirely or in parts. Nativeness in early bilingual children is less straightforward due to its gradual nature. Both languages of a bilingual speaker can be cognitively native, even if one language can be dominant over the other. This is complicated by the fact that bilingual acquisition can proceed in cognitive pathways unavailable to monolingual acquisition (see Grosjean 1989, and Kroll \& al. 2015 for a state of the art review). Bilingual acquisition cannot be reduced to an addition of monolingual acquisition processes. This result is very important for the assessment of nativeness. It could be tempting to consider that a simple comparison of the productions of monolinguals and of bilinguals would give us assessment of nativeness in a given language. However, this would be comparing the results

6 Similar obervations are made about Basque. Hualde (2015) proposes that "the two areas [of Basque] that are most likely to be affected in an important way are pronunciation and lexical semantics, including phraseology." 
of processes that we know to be different. Instead, in bilingual cases, assessment of nativeness can be achieved if there are demonstrable contrasts with the productions of late learners, including highly proficient late learners.

Interacting in one's non-native language takes on greater cognitive resources than interacting in one's native language. In Schutter's (2013:203) terms: "nearnative late L2 learners of a second language are perfectly capable of acquiring a native-like L2 grammar, but still produce non-native-like interface structures when pressurized through time and/or memory constraints". In other words, even if some late learners achieve near nativeness proficiency, they still react as second language speakers under linguistic stress. Even when both profiles of speakers have the same grammatical competences, L2 speakers bear stricter computational limitations that impact their performances.

Two different lines of evidence support this hypothesis. First, highly proficient L2 learners perform like natives would when under linguistic stress (comprehension tasks with additional white noise (McDonald 2006), fast grammaticality judgments (Hopp 2009)). Second, when both types of speakers undergo linguistic stress, their performances differ so as to reveal the native's advantage. Schutter (2013) has compared the syntactic competence and performance of native English speakers and advanced learners of English whose native language is Dutch. He uses linguistic stress in his elicitations so that speakers could no longer monitor their language comprehension and production (by shortened time window for answers, and overloads of the speakers working memory). He finds that, despite the non-natives being as aware of the correct structures as the natives, their online performance declined when they were placed under an extra processing load. In perception, the effect of white noise is also more dramatic on non-natives. Drozdova (2018) shows that there is a difference in language signal treatment between natives and non-natives when white noise is superimposed. Non-natives can learn to recognize unfamiliar voices and take recognition benefits from it, but they do not extend this advantage to lexical recognition, contrary to natives.

In the case of Breton, as is the case for endangered languages in general, the additional challenge in order to find evidence for (non)-nativeness is that the baseline is slippery. The speaker's performance and competence can be impacted by different factors: (i) late or incomplete learning, (ii) native impoverished input or (iii) installed diglossia leading to lexical impoverishment in a given social context. For illustration, the effect of non-nativeness on acoustic perception is well known in professional dubbing in the Breton film industry. J-M. Ollivier (p.c.) works as a sound engineer in Dizale, an association that provides Breton dubbing for films. He reports that the Breton voices that he superimposes on the films systematically have to be set to a louder volume than the original ones. If not, Breton speakers, both actors and spectators, complain 
"they don't hear properly". As far as linguistic production under pressure is concerned, actors and directors in the theatre can testify that after long and emotionally draining creative sessions, even very proficient L2 speakers find relief in some brief moments of exchange in French, whereas this trigger for code-switching is not expressed by inherited natives. I have a long experience of Breton theatre practice, and it is my perception that Breton speakers who had early schooling in Breton also show individual variation in that respect, depending mostly on their actual practice of the language.

A syntactic test can differentiate Breton speakers according to nativeness. The test consists of a translation task of a structure that is very simple in either French or English: these thirty-one rocks or those twenty-one pens. The Breton translation however poses serious syntactic problems. Breton dozen-plus-one cardinals are realized as discontinuous numeral (1). The head noun appears between the unity numeral and the dozen numeral. The unity /one/ is realized as unan in isolation or in continuous numerals. When it appears before the head noun however, like in a discontinuous numeral, its form is obligatorily that of an indefinite determiner $u n, u l, u r(1)$. This property makes it quite challenging to embed in a demonstrative, because demonstrative structures are also discontinuous, starting with an obligatory definite article like $a n, a l$, $\operatorname{ar}(2)$.

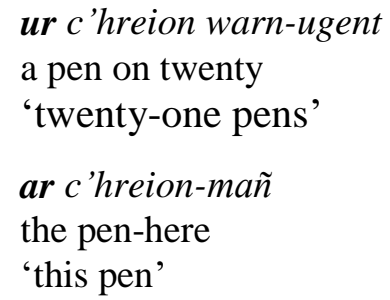

Forcing co-occurrence of the structures in (1) and (2) poses obvious problems, and all speakers comment on it. They have to decide how the two discontinuous structures are to be embedded the one inside the other. Both structures start with an article, but both seem incompatible because of a definiteness clash. Nowhere else in the language do two articles co-occur. Most speakers resist to the alignment of an ur at the beginning of a determiner phrase. The placement of the spatial deictic - mañ '-here' of the demonstrative inside that big compound is also often commented on, and speakers hesitate as to its cliticization host.

Both the reactions and the results to this test clearly set apart natives and non-natives. Even very proficient second language speakers of Breton typically stall, and have recourse to paraphrases as their only option. They typically refuse additional adjectives in the structure ('these thirty-one little/white/funny rocks') as an impossible overload. Second language speakers all have refused 
the alignment of an $u r \ldots$ or $u r$ an. A semi-early bilingual (first language contact at eleven years old) has provided the structure in (3). In his solution, a prepositional strategy alleviates the problem. The problem of adjective placement is evacuated by the use of a diminutive. This was the best attempt of four proficient but non-native speakers. All the others willingly tried but had to give up on translating a structure such as these thirty-one rocks.

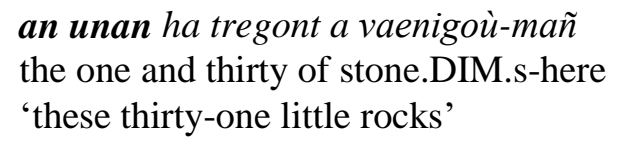

[M.S. (01/2018)]

Early natives, on the other hand, typically recognize that the translation is difficult, but they immediately have recourse to their internal intuition and end up providing a translation in which they have great confidence in less than a minute. Some natives even achieve the task in carrying the extra burden of adjective placement. Interestingly, the concrete syntactic solutions proposed by the natives are far from uniform. In the following of this section, I illustrate below some of their answers.

M. Lincoln was schooled in Diwan and was raised by second language parents in Leon. She has discontinuous numerals and she inserts the entire construction inside an analytical demonstrative as in (4). In (5), she allows for the an $u r . .$. collocation that has no counterpart in the language.

\section{Sell 'ta an [ div logodenn warn-ugent]-mañ !}

[M. Lincoln (01/2015)]

look then the two mouse on-twenty -here

'Look at these twenty-two mice!'

(5) an [ ur roc'h ha tregont ]-se the a rock and thirty -there

M. Lincoln [07/2016] 'those thirty one rocks' reported in Jouitteau (2018)

Brendan Corre is native of the inherited Treger variety via his mother. He has discontinuous numerals (6). When confronted with the additional demonstrative analytic form, he drops the indefinite $u r$ as a last resort strategy (7). Note that a lenition appears on the head noun for no apparent reason - this speaker otherwise treats min as a masculine noun (ur min, 'a rock'). The vowel may also have been altered, which could be the sign of inference of another dialect. Presented with the solution of M.L. in (5), the speaker has no hesitation to judge it strongly ungrammatical. 
'these thirty one white rocks.'

SLG. is native of the Leon variety via her mother, with a second language Breton-speaking father. She was raised partly in the UK and is not fluent in French. She is fully trilingual with English and Spanish. She has discontinuous numerals with an abnormal mutation system (8). Her strategy is also to drop an article, but she chooses to drop the definite article in the analytical demonstrative (9). Comparing the $u r$ and $u n$ forms of (8) and (9), it is possible that un in (9) could be an abbreviated form of the cardinal unan, but this instance of it would be before a head noun, contrary to the standard rule.

$$
\text { a pen and thirty }
$$

(9) un kreion ha tregont-mañ one pen and thirty-here 'these thirty-one pen'

J-M.O. conforms to the standard rule in allowing only for discontinuous numerals when a head noun is realized. However, when confronted with the demonstrative conundrum, he produces the continuous numeral as a last resort strategy, despite the presence of the head noun. In (10), un'/ən/ realizes an abbreviated form of unan 'one'. This analysis is confirmed by the speakers who pronounce the entire form, like SLG.'s mother, inherited native from the dialect of Leon in (11).

an un' ha tregont mein-se the one and thirty rock-there reported in Jouitteau (2018) 'those thirty one rocks.'

(11) an unan ha tregont kreion-mañ mother of SLG. the one and thirty pen-here 'these thirty one rocks.'

Speaker I.G., young adult who was schooled in Diwan, has no discontinuous numerals at all (12). In consequence, she has no problem to align the definite article an and the cardinal un (13), (14). 
(12) un ha tregont kreion bihan gwenn, daou ha tregont kreion bihan gwenn a and thirty pen little white two and thirty pen little white 'thirty one little white pens, thirty-two little white pens'

(13) an un ha tregont kreion-mañ the a and thirty pen-here 'these thirty pens'

(14) Kasit an un ha tregont logodennig-se maez dioustu!

Send the a and thirty mouse.DIM-here out now

[I.G. (08/2018)]

'Get rid of those thirty one mice right now!'

Like I.G., M.La. was schooled in Diwan but left the Diwan school before the lise (high school). She has no discontinuous numerals, and alternates freely the abbreviated and non-abbreviated forms un and unan of the cardinal 'one' as in (15). Note that both these speakers show an unexpected idiosyncrasy: for both of them, as I.G. comments on, a plural form of the noun is optionally allowed with the - se form of the demonstrative (16), (17). This would be ungrammatical in Standard Breton or, as far as I know, in traditional dialects where cardinals and plural nominal forms are incompatible.

an un ha tregont levr

[M.La. (08/2018)] the one and thirty book 'the thirty-one books'

(16) an unan ha tregont levrioù-se

[M.La. (08/2018)] the one and thirty books-there 'those thirty-one rocks'

(17) an un ha tregont kreionoù-se the one and thirty pens-there 'those thirty-one rocks'

Provided the above results, it is obvious that much has to be done in order to set apart, for Breton native speakers, what is inherited linguistic idiosyncrasy, syntactic individual creativeness or signs of language evolution under an impoverished sociology of the language. One conclusion however emerges: Breton natives, including speakers who had early Breton input only at school, do have answers for these translations, whereas very proficient second language speakers of the language do not. Linguistic stress and syntactic overload provide a test that sets apart natives and non-natives.

I conclude that children schooled early in Breton, with consistent input at school, should be included as natives. This of course has an impact when considering the presence of people who are actually Breton natives in the 
global population. This also has an impact on the estimations of Breton speakers who have received Breton at home: when early-schooled children have parents who do not speak Breton but have older siblings in the same school, one should not exclude the hypothesis that they in fact also have received early Breton input at home by their siblings. In the remainder of this paper, I will take stock of these results to discuss the sociolinguistic dimension of these findings.

In this first section, I have shown evidence for the cognitive nativeness of different profiles of young Breton speakers. This raises the question of their erasure in cultural representations. How does this happen, and why?

\section{Native Breton speakers and their erasure}

In this section, I address the culture of erasure of Breton native speakers. I first approach their invisibility in society. I show how the figure of native speakers of Breton in Lower Brittany approaches the symbolic figure of the ghost. Both figures are symbolically associated with a mythological past despite their invasion into the present. Concrete signs of their presence trigger social anxiety because the available cultural representations suppose their non-existence. They are paradoxically said to be everywhere, but are mostly invisible.

\subsection{Invisibility in society}

The lack of visibility for Breton speakers in general is first due to the absolute numbers of speakers, which are now quite low (Broudic 2010 and references therein). The total number of speakers was estimated at 1100000 people around 1950. Since the end of the Second World War, Breton has lost $85 \%$ of its speakers in 60 years (Broudic 2009). According to the TMO Regions Institute survey (2007), 172,000 Breton speakers (90\%) resided in Western Brittany, a drop of $30 \%$ in ten years since the estimation of 1999. In 2007, only 35,000 speakers declared using Breton daily, and occasional practice is clearly predominant. Broudic (2010) estimates there are only 12,000 speakers of Breton in the age group of 25-50 years, many of them L2 speakers with great individual differences in their command of the language. The social spaces associated with the practice of Breton are more and more restricted. In 2018, the Regional council has published an estimation of over 200.000 Breton speakers, which is surprisingly high compared to the previous numbers (see TMO 2018, and Jakez 2018 for discussion). The number of speakers could have been slightly underestimated, because all surveys so far have relied on self-reporting (as opposed to actual translation abilities, see Rybková 
2012). Uncertainty in the exact number of speakers does not shed doubt on the fact that the global situation is a fast decrease in the number of speakers. ${ }^{7}$

The Breton language still lacks societal visibility outside of museography and bilingual road signs. First, Breton speakers are an invisible minority. They are not detectable when they speak French, as they show the same local accents than French monolinguals. Second, the language innovates social places for the language that have in common to remain inconspicuous to non-Breton speakers. The largest periodical $Y a$ had 1,200 subscribers in 2010, and some other titles for teenagers and children also exist, but non-Breton speakers would not see it on a newsstand because Breton press is available only by subscription. On the television, the public service broadcasts only 70 hours of programmes in Breton per year, and four radios broadcast partially or exclusively in Breton on their respective territories. Most of Breton visibility is now on the Internet. The webTV Brezhoweb offers a monthly program in the form of a two-hour talk show and various other programs (sitcom, youth show, dubbing films ...). Radios offer podcasts. Social media provide space for Breton-speaking groups for free, search engines make them easy to reach. Job announcements in Breton can be found on the website of the OPAB or Ubapar (Union Bretonne pour l'Animation des Pays Ruraux, 'Breton union for rural area activities'). These new tools are easily accessible to anyone who looks for it, but remain perfectly inconspicuous to non-Breton speakers. In 2007, the Office of the Breton Language has created "spilhennig", a badge for Breton speakers to wear on their clothes in order to recognize themselves in public. Again, the logo is not self-explanatory and tells nothing to non-Breton speakers. As a result, in the same neighbourhood, some people can live a bilingual life with Breton as a dominant language, and their neighbor can ignore the very possibility of it.

\subsection{Symbolic association with the past}

The symbolic association of the Breton language with the past participates in its erasure. This effect is most clear in the profile of speakers that come from

7 Rybková (2012) finds in her pilot study that self-declaration and actual mastering of the language may differ for Breton. She finds that 35\% (compare with the 25\% of TMO 2007) of respondents can express themselves in Breton with high or middle accuracy, and translate from French to Breton. Her results still have to be replicated because she had operated on a small sample of only 108 speakers. 20 respondents also joined the sample by personal demand, which induces a bias towards militant and/or fluent Breton speakers. In contrast with Breton, Welsh speakers tend to over-report themselves as good Welsh speakers. Jones (2018) reports that for FMRI testing procedures on Welsh speakers in Wales, overestimations of selfreported linguistic abilities are to be expected. Jones had to eliminate some subjects from the study because they had declared themselves bilingual, whereas their abilities turned out to be too limited for them to be included in the study. 
Breton speaking families but do not speak it themselves. For them, intimately, Breton is associated with their own ancestors, as well as with their familial or personal linguistic rupture with them. Symbolically, Breton stands as a notion meaningfully opposed to their familial present. If they were aware of the various actual Breton practices in their present, these non-Breton speakers could consider that the Breton/past association, while relevant to their family history, is less so to contemporary Breton speakers. Instead, when confronted with expressions of the language by both natives and L2 speakers, they show different forms of resentment. A classic one is to reproach (in French) young Breton speakers that their Breton fails to reproduce the intonation that they were used to hearing with their relatives. Much work needs to be done on the specific attitude of non-Breton speakers towards Breton. When discussion is possible, they report to experience a cocktail of shame, jealousy or fear. Some fear the reenaction of the linguistic social stigma on the lower social classes that were the last to reach access to French. Some individuals interpret others speaking Breton as a comment on their own linguistic disability, or as a sign of voluntary exclusion, leading to much distress and triggering various defence mechanisms.

The confusion between monolinguals and natives feeds the representation, against factual data, that Breton is not spoken natively anymore. The low visibility of Breton speaking practices adds to this effect, to the point that real world manifestations of Breton speakers can be perceived as anachronistic and ultimately frightening: the symbolic figure of the Breton speaker is at the same time dead and alive. This representation feeds itself: any manifestation of Breton in modern life then becomes a proof of its ghost nature, and is disqualified as a sign of vitality. ${ }^{8}$

\subsection{Some concrete examples of cultural erasure}

As a linguist working on Breton for two decades, I have encountered numerous reactions in France with respect to my object of study. I found some of them particularly telling because they show the same logic conundrum: French citizens tend to have strong opinions on Breton speakers but they claim at the same time that those people do not exist. This cognitive dissonance is remarkable and leads to emotionally charged reactions, in which logic seems particularly challenged. This section aims at providing non-French readers with some concrete examples of how social erasure of Breton natives plays in Brittany. These examples are not supposed to convince the reader, because they remain fundamentally anecdotal facts. They are aimed at displaying the kind of

8 For the ethnopsychiatric hypothesis that Celtic cultures accomadate subworlds and "doublerealities" in their representation of their present, see Carrer (1999:131). 
syllogisms and logic conundrums typically encountered in fieldwork on nonFrench languages in France. These reactions may seem illogical, and they are. They follow however a very clear logic, internal to French culture.

In 2013, I was introduced during a social event to a private physiotherapist in Brest. The man, in his thirties, asked for my advice as a linguist on a professional matter. He had recently worked with a family whose parents addressed their child of pre-school age in Breton during a consultation. His question to me was if he should have reported the parents to social services for child abuse. I told him that in my opinion, no harm was done to the child by speaking a language to him. He was worrying about the child's access to French. I assured him that the overwhelming presence of the French language in Breton society would provide the child with enough input for her to end up bilingual. The physiotherapist then expressed the concern that this child would then speak Breton, a language that "nobody really speaks". I could not make him see the complete circularity of his argument: his first concern had been that people were indeed speaking it family-internally. He was genuinely worried, and seemed fully unaware of the discriminating dimension of his concern, not to mention the aggravating circumstance of it coming from professional medical care. This child, as a native Breton speaker, finds herself in a rather peculiar situation: her existence is felt shocking because of her very presupposed nonexistence. She produces the effect of a ghost.

Academia is not exempt from the ghost effect on Breton native speakers, not even linguists. When I was studying at the university of Nantes, a psycho-linguist teacher refused Breton as my topic of choice for the paper of his class on language acquisition. I had proposed this topic for practical reasons because I was teaching in the neighbouring Breton immersion Diwan school at the time, and had the access and trust that would have made the research easy with the families. His justification for refusal was that the entire enterprise was undoable because of a supposed impossibility that the children were speaking Breton at home ("Don't tell me Breton mummies play peek-a-boo in Breton with their babies!" he commanded). It is important to note that in academia, the unchecked belief that a phenomenon is non-existent was performative: this teacher's attitude ensured the non-existence of that particular study on that particular phenomenon, and so participated in its erasure from academic research and discourse.

Native speakers themselves are not immune to this ghost effect. Numerous times have I had people telling me in Breton that they were not Breton speakers, let alone natives, to the point that I started considering it as first contact classic in elicitations. The same speakers could five minutes later explain that they were Breton monolinguals for the seven to eight first years of their pre-school life, and that they never interrupted practice of the language. This self-erasure is consistent with a widely noticed self-depreciation of linguistic authenticity, 
such as reported by Adkins (2013) who describes speakers displaying a tendency to assess their own Breton as inferior, uneducated, and imperfect (see also Moal 2016).

In the last section, I concentrate on the erasure of Breton native speakers in academic discourse itself.

\subsection{Erasure in academic discourse: natives vs. new speakers}

The notion of the new speaker is emerging as a central notion in the field of the sociolinguistic of minority languages in Europe (O'Rourke and Pujolar 2013, Smith-Christmas et al 2018, among many others, and for Breton: Hornsby 2014, Moal 2017, Davies-Deacon 2017, Moal \& al. 2018, Kasstan 2019 ...). The figure of the new speaker is explicitly constructed around second-language learners, and is used in opposition to the figure of the native speaker. In (18) and (19), emphasis in bold has been added by me. ${ }^{9}$

(18) "The new speaker label is used in work on language endangerment and revitalization to characterize the lived experiences and sociolinguistic realities of individuals who acquire a minority language not through traditional transmission contexts (e.g. home, family), but as adults through revitalization initiatives (O'Rourke et al. 2015)." Kasstan (2019)

(19) "New speakers, from this perspective, are all multilingual citizens who, by engaging with languages other than their "native" or "national" language(s), need to cross existing social boundaries, re-evaluate their own levels of linguistic competence and creatively (re)structure their

9 An anonymous reviewer points out that the notion of new speaker does not necessarily always exclude natives ("the term new speaker usually implies that the speaker has not acquired a traditional variety of the language at home from their parents in the normal way, but that does not necessarily mean they are "non-natives' or have the characteristics of an L2 learner"). Indeed, O'Rourke and al. (2015: 1) and McLeod and O'Rourke (2015:1) define new speakers as "individuals with little or no home or community exposure to a minority language but who instead acquire it through immersion or bilingual educational programmes, revitalization projects or as adult language learners'. McLeod and O'Rourke (2015:1) however next proceed to a careful exploration of the contrast between... new speakers and natives. Some articles prefer to systematize the opposition new/traditional speaker (e.g. Nance 2015). The fact is that the notion of new speaker sometimes explicitly excludes and sometimes explicitly includes natives, and some other times is used without explicit definition of its content with respect to nativeness of the speakers, which allows for alternative interpretations. My point is that this terminological lack of clarity leads to the overall conflation of profiles of speakers that are cognitively different, a difference which is sometimes relevant across different fields of linguistics. 
social practices to adapt to new and overlapping linguistic spaces." Description of the COST European program, IS1306 - New Speakers in a Multilingual Europe - Opportunities and Challenges https://www.cost.eu/ actions/IS1306

Multilingualism in Europe and the cultural representations of late-learners is of great interest for the future of minority languages, some of which are now greatly endangered. However, this terminology implicates that the younger generations of Breton speakers, the new speakers, are all non-natives. As noted by Nance (2015), in Brittany, this choice of terminology is in line with the term of neo-Breton speaker as used in Le Dû (1997), who considers explicitly that there is "a ditch separating neo-Breton speakers and speakers of inherited varieties". 10,11

The first problem is that this terminology neglects the social existence and relevance of two types of young native speakers. First, the young speakers of inherited Breton, and second, the young speakers who had consistent Breton input before the age of five years old by early schooling in immersion systems.

10 Le Dû (1997): "les difficultés d'intercompréhension orale entre bretonnants de régions diverses sont bien connues, sinon exagérées, sans parler du fossé qui sépare néo-bretonnants et locuteurs des parlers hérités". The French term néo-bretonnant adds a terminological confusion with 'speakers of a new form of Breton'. The suffix -onnant imports a pejorative dimension to the term, due to an imperfective effect (chanter 'to sing' > chantonner 'to sing imperfectly, partially or without the lyrics' or mâcher 'to chew' > mâchonner 'to chew imperfectly, or without ending point', see Tovena and Kihm 2008 for an analysis of this suffix in Romance). This pejorative derivation is not available for 'French speaker' (francophone but *franconnant, \#francisant). A reviewer suggests that the choice of the-onnant /onã/ suffix simply derives from the language name Breton ending in the nasal vowel / $/$ /. However, the morphologically regular brittophone is available, with the desired non-pejorative semantic reading of 'Breton speaker'. The suffix -onnant is also not restricted to nasal endings (neither chantonner nor mâchonner above end in a nasal vowel). The -on ending does favours the choice of -onnant, but only over its variant -isant that has the same pejorative/imperfective meaning. In French, speakers of non-French languages are commonly refered to by such derivations in -isant. When the language is of low status, the two forms tend to alternate, like in occitanisant vs. occitanophone 'Occitan speaker'. When the language has State status, the use of the two forms is clearly differentiated hispanisant 'speaker or object of Spanish style or somehow related to Spanish or Spain' vs. hispanophone 'Spanish speaker (neutral)'.

11 The notion of nativeness is hard to grasp in Jones $(1995,1998)$. She states that standardized literary Breton has "no particular French influence", but that its spoken version "shows French influence in its syntax but not in its lexicon". She next derives this supposed difference between the oral and written forms by postulating that the oral form is spoken by néobretonnants, defined as non-natives. This amounts to saying that only diatopic varieties are natively spoken. However, in her conclusion, Jones (1995) makes the prediction that Standard Breton will in the future become what she calls a "xenolect", a term she defines as a "slightly foreignized varieties spoken natively, which are not Creoles because they have not undergone significant restructuring". 
The second problem is that this terminology is not consistent. The term new speaker sometimes explicitly includes or explicitly excludes, some other times is used without explicit definition of its content with respect to nativeness. The notion can also vary so as to approach the production of young modern speakers in general and to draw from it conclusions on non-native new speakers, or the opposite. For illustration, when Davies-Deacon (2017) observes the Breton lexicon used on social media, she is studying the conversations of Breton speakers having access to the Internet, that is the conversations of both natives and non-natives. Her conclusions bear on speakers with historically new communication habits and new sociological profiles, but not precisely on new speakers defined as non-natives. The presence of native productions in social media opens the question of their linguistic influence on the other speakers. This question cannot be addressed without a terminology that allows for denotation of native new speakers.

The new speaker terminology is aimed at preventing the museification and essentialization of native speakers (O'Rourke and Pujolar 2013:53), but its consequence, when it negates the existence of new profiles of young natives, is to freeze the figure of natives modeled on a heraldic representation of the older generations. The negation of the existence of young natives, sometimes explicit and sometimes by implication, adds to the already minority situation of Breton native speakers among other young Breton speakers, inside the broader minority context of the Breton language. This negation of existence is detrimental because it is also performative, a property which I will illustrate with two concrete examples. Every year in the autumn, a large promotional campaign places posters all across Brittany advertising for Breton classes for adults (J'apprends le breton! I learn Breton!'). To non-Breton-speakers, such campaigns represent the most conspicuous sign of the presence of Breton in society. For natives however, these posters are merely a reminder of their minorized situation because the addressee of the poster has to learn the language in order to speak it. This message in fine participates in their symbolic erasure from the collective representation. The same problem is noticeable concerning cultural events in the Breton language. Public linguistic policies that are directed towards new speakers need to ensure that the cultural events provide adequate pedagogical material for language learning. Public servants find themselves in a position of judging what artistic creation deserves public financial support with a language learning criteria in mind. Artists and cultural structures of course behave accordingly. This would be destructive in any language, but it is disastrous in the case of the fragile artistic structures in minority languages. From the point of view of natives, having cultural provision answering pedagogical criteria is of no interest, as it only impoverishes the cultural provision available to them. 


\section{Conclusion}

I have shown that there are objective signs of cognitive nativeness in different profiles of young Breton speakers. Immersion nurseries and early schooling can provide speakers with sufficiently early input to react to syntactic tests as native speakers once they have reached adulthood. I have discussed a pilot study that induces linguistic stress on syntactic structures. The test tells apart natives from second language learners, and provides linguistic evidence for two classes of young Breton native speakers: on the one hand, traditional young natives with parental linguistic input, and on the other hand, natives whose early input comes only from early consistent Breton immersion schooling. The representation that native Breton speakers exclusively pertain to the older or long gone generations is thus inaccurate. It should be rejected as such in the field of linguistics, and studied for its very inaccuracy in the field of sociolinguistics.

More research is of course needed on the syntax of the minority of young speakers that demonstrate nativeness in their language, in order to understand how their language evolves (or not) in its heavily diglossic context. The emergent research field of heritage languages is promising in this respect, because it provides tools to study linguistic native varieties with input impoverishment. Language policies in this regard have to concentrate on the quality of the early linguistic input received by children. Language policies should for example ensure that insufficiently secure L2 speakers don't find themselves choosing to work in nurseries or young children's classes on the hope that it could be less linguistically challenging than working with older children. Much remains to be done concerning the syntactic competence and sociological influence of the different profiles of natives of the Breton language, including also a profile that is not addressed here: the passive speakers (9\% of the Breton self-declared "speakers" in Karaez, OPAB 2014).

Concerning the sociolinguistic approach of Breton speakers, the very existence of young Breton natives calls into question the widely used notion of new speaker as excluding natives. As long as the notion of new speaker is constructed in opposition to speakers demonstrating linguistic nativeness, the notion of new speakers co-organizes the erasure of young native speakers by evacuating them from the representations of modernity. This is scientifically inaccurate, and directly detrimental to those speakers who live in an already minorized situation. Ultimately, it can also be detrimental to language revitalization policies, which concentrate their efforts on second language learners without valorizing the existing linguistic richness and potential of their young generations of natives. The new speaker paradigm is a social category, not a linguistic one. It centres on membership of the speech community - or not - and the use of authentic language by legitimate speakers. The present paper 
paves the way for a sociological approach of native new speakers. Are they considered authentic and legitimate in their own community? How do young native speakers of minority languages receive the social representation of new speakers? How do they perceive the scientific literature which feeds revitalization programmes, when this literature reproduces the (sometimes explicit) presupposition that because they have acquired a minority language at an early age, they have poor access to the internet, struggle with reading and have low access to the Standard? In their view, does this presupposition align with the traditional prejudice against minority languages? Do young adults raising their children in their own native minority language take it proudly that their children are literally called old speakers? It may well be the case in Basque, where the translation for native speaker is euskaldun zaharrak literally /basque.speaker old.PL/, but less so in Breton where native speaker translates as unan a-vihanig /one from-little.diminutive/. I have argued that the term of native speaker is necessary in the field of sociolinguistics in order to address these issues.

\section{REFERENCES}

Adkins, Madeleine. 2013. 'Will the real Breton please stand up? Language revitalization and the problem of authentic language', International Journal of the Sociology of Language, $55-70$.

Bader, Markus \& Jana Häussler. 2010. Toward a Model of Grammaticality Judgments, Journal of Linguistics 46:2, 273-330.

Broudic, Fañch. 2009. Parler breton au XXIe siècle. Le nouveau sondage de TMORégions. Brest: Emgleo Breiz.

Broudic, Fañch. 2010. 'Breton', Mélanie Jouitteau (éd.), Entrelangues, https:// entrelangues.iker.univ-pau.fr, accessed [11/09/2018].

Carrer, Philippe. 1999. 'Etats limites et champs ethnoculturel', L'envers du décor, ethnopsychiatrie en Bretagne et autres terres celtes, Coop Breizh, 125-132.

COST Action IS1306 - New Speakers in a Multilingual Europe - Opportunities and Challenges, https://www.cost.eu/actions/IS1306 [accessed 27/11/2019].

Díaz B, Erdocia K, de Menezes RF, Mueller JL, Sebastián-Gallés N, Laka I. 2016. 'Electrophysiological Correlates of Second-Language Syntactic Processes Are Related to Native and Second Language Distance Regardless of Age of Acquisition', Frontiers in Psychology 7: 133.

Davalan, Nikolaz. 1999. 'Interférences linguistiques chez des enfants scolarisés en breton', Francis Favereau (éd.), Le Bilinguisme précoce en Bretagne, en pays celtiques et en Europe atlantique, Actes du Colloque international de Plésidy (Côtes-d'Armor) octobre 1997, Klask 5, Presses universitaires de Rennes, 97-118.

Davies, Alan. 2013. 'Is the native speaker dead?', Histoire Épistémologie Langage 35/2: 17-28.

Davies-Deacon, Merryn. 2017. 'The online presence of standard and non-standard Breton', paper 
presented at Multilingualism: Empowering Individuals, Transforming Societies, University of Durham, 4th July 2017.

Dehaene, Stanislas, E. Dupoux, J. Mehler, L. Cohen, E. Paulesu, D. Perani, P. F. Van de Moortele, Stéphane Lehéricy, D. Le Bihan. 1997. 'Anatomical variability in the cortical representation of first and second language', NeuroReport, 8 (17), 3809-15, Lippincott, Williams \& Wilkins.

Dołowy-Rybińska, Nicole. 2017. 'Language learners or new speakers: the transfer of the Breton Diwan immersion education model to the lower Sorbian Witaj project', Studia Celtica Posnaniensia 2 (1), 5-26.

Drozdova, Polina Aleksandrovna. 2018. The effects of nativeness and background noise on the perceptual learning of voices and ambiguous sounds, PhD. Thesis, U. Neimejen, LOT Publication.

Laka, Itziar, Mikel Santesteban, Kepa Erdocia, Adam Zawiszewski. 2012. 'The Basque language in the minds of native and non-native bilinguals', The challenge of a bilingual society in the Basque Country, 157-172.

Le Dû, Jean. 1997. 'Le Breton au XX⿳亠口冋 ${ }^{\circ}$ siècle: renaissance ou création?', Zeitschrift für Celtische Philologie 49-50, 414-431.

Goldin-Meadow, Susan. 2003. The resilience of language: What gesture creation in deaf children can tell us about how all children learn language. New York: Psychology Press.

Grosjean, François. 1989. 'Neurolinguists, beware! The bilingual is not two monolinguals in one person', 'Brain Lang'. 36: 3-15.

Hopp, Holger. 2009. 'The syntax-discourse interface in near-native L2 acquisition: off-line and on-line performance', Bilingualism: Language and Cognition 12 (4), 463-483.

Hornsby, Michael. 2014. 'The "new" and "traditional" speaker dichotomy: bridging the gap', International Journal of the Sociology of Language 231: 107-125.

Hualde, Jose Ignacio. 2015. 'Basque as an extinct language', B. Fernández \& P. Salaburu (arg.), Ibon Sarasola, gorazarre, Bilbo, UPV/EHU, 319-326.

Jakez, Fulup. 2018. 'Niver ar vrezhonegerien : stabil or not stabil ?', http://www.dispak.bzh/ niver-ar-vrezhonegerien-stabil-or-not-stabil/, oct 9, [retrieved oct 12].

Jones, Mari C. 1995. 'At what price language maintenance? Standardization in Modern Breton', French Studies 49 (4): 424-438.

Jones, Mari C. 1998. 'Death of a Language, Birth of an Identity: Brittany and the Bretons', Language Problems and Language Planning 22 (2), 129-142.

Jones, Samuel Kyle. 2018. 'Using the Welsh language as a measure of neural resistance to cognitive decline and Dementia', presentation at the $3^{\text {rd }}$ Celtic conference in Poznan, July 2018.

Jouitteau, Mélanie. 2018. 'Children Prefer Natives, a study on the transmission of a heritage language; Standard Breton, Neo-Breton and traditional dialects', Maria Bloch and Mark Ó Fionnáin (eds.), Centres and Peripheries in Celtic Linguistics, Lublin, Peter Lang, 75-108. https://ling.auf.net/lingbuzz/003988.

Jouitteau, Mélanie. 2019. 'Standard Breton, Traditional Dialects and How They Differ Syntactically', Journal of Celtic Linguistics 21, 29-74.

Kasstan, Jonathan. 2019. 'Emergent sociolinguistic variation in severe language endangerment', Language and Society, Cambridge University Press, 1-36.

Kennard, Holly J., 2014. 'The persistence of verb second in negative utterances in Breton', Journal of Historical Linguistics 4(1), 1-39.

Kennard, Holly J. 2018. 'Non-Negative Word Order In Breton: Maintaining Verb-Second', Transactions of the Philological Society, 1-26. 
Kim, Karl H. S., Norman R. Relkin, Kyoung-Min Lee, Joy Hirsch. 1997. Distinct cortical areas associated with native and second languages, Nature 388, 171-174.

Kroll, Judith F., Paola E. Dussias, Kinsey Bice \& Lauren Perrotti. 2015. 'Bilingualism, Mind, and Brain', Annual Review of Linguistics 1: 377-394.

Lenneberg, Eric H. 1967. Biological foundations of language, New-York, Wiley.

McLeod, W. \& O'Rourke, B. (2015). “New speakers” of Gaelic: Perceptions of linguistic authenticity and appropriateness', Applied Linguistics Review, 6, 151-172.

Makin, Simon. 2015. 'Debate Rages over Whether Speaking a Second Language Improves Cognition', Scientific American, Dec 30.

Mayberry, Rachel. 1993. 'First language acquisition after childhood differs from second-language acquisition: The case of American Sign Language', Journal of Speech and Hearing research 36: 1258-70.

McDonald, Janet L. 2006. 'Beyond the critical period: processing-based explanations for poor grammaticality judgement performance by late second language learners', Journal of Memory and Language 55, 381-401.

Mermet, Michel. 2006. Informatique et maîtrise de l'oral en maternelle bilingue breton-français. modèle de l'élève dans le dialogue enfant-ordinateur et ergonomie de la parole en breton, unpublished $\mathrm{PhD}$ ms. U. Roazhon.

Moal, Stefan. 2016. 'Locuteurs traditionnels et nouveaux locuteurs de langue bretonne : un autoodi peut en cacher un autre', Carmen Alén Garabato \& Romain Colonna (éds.), Autoodi. La "haine de soi" en sociolinguistique, Paris, L'Harmattan, coll "Sociolinguistique", 119-144.

Moal, Stefan. 2017. 'Traditional and new speakers of Breton : the transmission challenge', Europäisches Journal für Minderheitenfragen / European Journal of Minority Studies, EJM, Vol. 10: 3-4, 208-230.

Moal Stefan, Ó Murchadha Noel \& Walsh John. 2018. 'New speakers and language in the media: Audience design in Breton and Irish broadcast media', Smith-Christmas, Cassie, Noel P. Ó Murchadha, Michael Hornsby, Máiréad Moriarty (eds.), New Speakers and Minority Languages: Linguistic Ideologies and Practices, Basingstokes, PalgraveMacmillan.

Nance, Claire. 2015. "New' Scottish Gaelic speakers in Glasgow: A phonetic study of language revitalisation', Language in Society, 44, 553-579.

OPAB, Ofis Publik ar Brezhoneg. 'Marc'had al labour', http://www.brezhoneg.bzh/73-marchad-allabour.htm [accessed 27/11/2019].

OPAB, Ofis Publik ar Brezhoneg. 2014. Enquête d'initiative locale sur la pratique du breton à Carhaix. http://www.fr.brezhoneg.

OPAB, Ofis Publik ar Brezhoneg. 2017. La langue bretonne dans le secteur de l'accueil du jeune enfant en 2016. http://www.fr.brezhoneg.

O'Rourke, Bernadette and Joan Pujolar. 2013. 'From native speakers to "new speakers" problematizing nativeness in language revitalization contexts', Histoire Épistémologie Langage 35: 2, 47-67.

O'Rourke, Bernadette, Joan Pujolar and Fernando Ramallo. 2015. 'New speakers of minority languages: the challenging opportunity - Foreword', International Journal of the Sociology of Language 231, 1-20.

Le Pelleter, Stéphanie. 2018. 'Ar magourioù dre soubidigezh', Al Lanv, meurzh 2018, 27-34.

Le Pelleter, Stéphanie. 2017. 'Breton et petite enfance: vingt ans d'actions', Le Peuple Breton, 1p.

Penfield, Wilder and Lamar Roberts. 1959. Speech and Brain Mechanisms, Princeton: Princeton University Press. 
Pierce, Lara J., Jen-Kai Chen, Audrey Delcenserie, Fred Genesee and Denise Klein. 2015. 'Past experience shapes ongoing neural patterns for language', Nature Communications 6: 10073.

Rampton, M. Ben. 1990. Displacing the 'native speaker': Expertise, affiliation, and inheritance. ELT Journal 44: 2, 97-101.

Rondal, Jean A. 1995. Exceptional Language Development in Down Syndrome, Cambridge, Cambridge University Press.

Rybková, Hana. 2012. Le breton et son influence sur le français local. Situation linguistique dans le Finistère, undergraduate thesis, University of Brno.

Schutter, John-Sebastian. 2013. An investigation into near-nativeness at the syntax-lexicon interface: evidence from Dutch learners of English, $\mathrm{PhD}$ ms, U. Edinburgh.

Smith-Christmas, Cassie, Noel P. Ó Murchadha, Michael Hornsby, Máiréad Moriarty (eds.). 2018. New speakers of minority languages, Linguistic ideologies and practices, Basingstokes, Palgrave-Macmillan.

Smith, Neil. 2002. Language, Bananas \& Bonobos; Linguistic Problems, Puzzles and Polemics, Blackwell Publishers.

Stephens, Janig. 2000. 'The development of grammatical structures in the Breton of nursery school children', Ikastaria 12, 123-142.

Sprouse, Jon, and Almeida, Diogo. 2012. Assessing the reliability of textbook data in syntax: Adger's "Core Syntax", Journal of Linguistics, 48: 3, 609-652.

TMO Régions. 2018. Enquête sociolinguistique sur le breton et le gallo, Communiqué de presse sur les résultats [4 octobre 2018].

TMO Régions. 2007. results as reported in Broudic (2009).

Tovena, Lucia M. and Alain Kihm. 2008. 'Event internal pluractional verbs in some Romance languages', Recherches linguistiques de Vincennes 37, http://journals.openedition. org/rlv/1687 ; DOI : 10.4000/rlv.1687

UBAPAR, Union Bretonne pour l'Animation des Pays Ruraux, 'Kinnigoù labour', https://www.ubapar.bzh/spip.php?rubrique9\&lang=br [accessed 27/11/2019].

Vargha-Khadem, Faraneh, Lucinda J. Carr, Elisabeth Isaacs, Edward Brett, Christopher Adams, and Mortimer Mishkin. 1997. 'Onset of speech after left hemispherectomy in a nineyear-old boy', Brain 120: 159-82.

Wattendorf, Elise., Brigit Westermann, Daniela Zappatore, Rita Franceschini and Georges Lüdi. 2001. 'Different languages activate different subfields in Broca area', NeuroImage 6 (13), 624 